government is emphasising cost containment is difficult. Some believe that the solution rests in a greater federal commitment to a comprehensive and equitable health care system; others are less confident in the government's ability to develop cost effective systems that are not open to abuse. The discussion will surely continue, but discussions and reports alone will not make the problem go away.

George Dunea Chairman of the division of nephrology/hypertension

KEVIN B WeISS

Cook County Hospital, Attending physician

Chicago,

Illinois 60612-9985,

USA

1 Heckler MM. Report of the secretary's task force on black and white minority health. Volume 1 , Executive Summary. Washington DC: US Government Printing Office, 1985. (US Department of Health and Human Services.)

2 National Center for Health Statistics. Vital statistics of the US, 1979. Volume 2, Mortality. Part A Table 1.1. Washington DC: US Government Printing Office, 1984. (Department of Health and Human Services publication number (PHS) 84-1101.)

3 Kleinman JC, Gold M, Makuc D. Use of ambulatory medical care by the poor: another look at equity. Med Care 1981;19:1011-29.

4 Aday LA, Anderson RM. The national profile of access to medical care: where do we stand? Am $\mathcal{J}$ Public Health 1984;74:1331-9.

5 Drew Ivie S. Ending discrimination in health care: a dream offered. Washington DC: US Civil Rights Commission, 1980. (National Technical Information Service publication number HRP 0903040.)

6 Mydral G. An American dilemma; the negro problem and modern democracy. New York: Harper, 1944.

\section{Real and imaginary halitosis}

The first question to ask yourself when confronted with a patient who complains of bad breath is: "Can I smell it?" If you cannot then you are probably dealing with a patient with a psychological problem. If you can then a rational approach to the differential diagnosis is possible.

Paradoxically the breath of those who complain vociferously about its offensive odour usually smells sweet, whereas those with unpleasant breath do not notice it. Yet imaginary halitosis is worse than real halitosis for it can become an obsession that dominates the victim's life and turns him into a social outcast. In some of those with imaginary halitosis it is a solitary delusion based on hypochondriasis, ${ }^{1}$ which may respond to reassurance or behavioural psychotherapy. If the diagnosis can be made then the patient may be saved from going from specialist to specialist in the vain hope of cure and protected from operations on the tonsils and sinuses and other futile treatments. Others who complain of halitosis and yet have normal smelling breath may be suffering from depression, which may respond to specific treatment. ${ }^{2}$ In a study of 137 patients who were troubled with smells, 36 seemed to have hypochondriasis and 50 a depressive illness; most of the rest had schizophrenia or temporal lobe epilepsy and suffered from olfactory hallucinations. ${ }^{3}$

Odours are difficult to measure. There are wide subjective variations in when people can begin to smell a smell and how intensively it seems to them. ${ }^{4}$ A typical chromatogram from someone with halitosis shows three peaks $s^{5}$ : hydrogen sulphide is the highest; methyl mercaptan is the next highest but is the best indicator of odour intensity as it is the most objectionable and is smelt at lower concentrations; the third peak is dimethyl sulphide, which is only a minor component. These volatile sulphur containing compounds are produced in $\underline{\underline{T}}$ the mouth by various Gram negative bacteria acting on $\frac{\mathbb{\Phi}}{3}$ proteinaceous material such as degenerated epithelial cells $\propto$ and leucocytes, damaged tissue, and food particles. ${ }^{6.8}$ This material collects on the tongue or is trapped in pockets $\frac{\rho}{\overline{5}}$ caused by periodontal disease. That this putrefactive process $D$ is worsened by poor oral hygiene was shown by an "experi- $\$$ mental gingivitis trial" in which 10 volunteer dental students stopped cleaning their teeth for 30 days. ${ }^{9}$

An unpleasant breath on awakening is normal, for the self $\overrightarrow{\bar{s}}$ cleansing mechanisms of the mouth-flow of saliva and theo movements of tongue and cheeks-cease during the night. But this morning halitosis soon disappears, and the doctor $\frac{\bar{s}}{\overline{5}}$ must look for other causes in the patient whose breath smells $\varnothing$ bad to him. Halitosis usually stems from the mouth and may be less common now that dental health has improved, but it $\vec{\circ}$ still occurs in the mentally retarded and handicapped who:find it difficult to clean their teeth or dentures. Any $\vec{\sigma}$ inflammation results in an increase of bacteria and dis- $\bar{O}$ integrating cells and so creates odour, and neoplasms ulcerate or become necrotic; also bacteria flourish when the flow of 0 saliva is reduced, so the breath is affected in fevers, $\dot{\circ}$ dehydration, and diseases of the salivary glands, like Sjögren's syndrome. Conditions such as acute ulcerative gingivitis and septic throat caused by agranulocytosis are usually easily응 recognised, as are obvious lesions in the nose, but a purulent음 discharge from sinusitis can be overlooked: a calcified foreign body-probably a pellet of paper that had been there for $c$ many years-explained the foul smell coming from a boy of 11 years. ${ }^{10}$ Diseases of the lower respiratory tract, such as bronchiectasis and abscess or gangrene of the lung are unlikely to escape attention.

Enemas and purgatives used to be prescribed for halitosis. on the assumption that it was of gastroenterological origin, but this is rare. Occasionally patients with pyloric stenosis have first complained that their breath smelt like rotten eggs as hydrogen sulphide is produced by bacteria in the stomach. ${ }^{11}$ But the flavoured belch of the aerophagist is usually pleasant and depends on the previous meal. Patientso with a gastrocolic fistula have complained that their breath is ${ }_{-}^{3}$ like "bowel wind," but fortunately the aromatic substances responsible for faecal smells are either not absorbed from the colon or are detoxified by the liver before reaching the lungs. The same may apply to the small intestine for halitosis from:bacterial overgrowth is not a sign of the stagnant bowel 3 . syndrome.

Drugs can alter the breath. Anticholinergics reduce the flow of saliva and encourage organisms to grow, and sub-음 lingual isosorbide causes halitosis. ${ }^{12}$ The arcma of paral- $N$ dehyde pervades the air around the patient, and carbon $\square$ disulphide is exhaled by anyone taking disulfiram. ${ }^{13}$ Toxicol-o ogists describe the garlic like smell from patients poisoned by arsenic, selenium, phosphorous, and tellenium..$^{14}$

The volatile compounds, of certain foods-onions ando alcohol, for example - are absorbed and excreted througho the lungs. One experiment showed that garlic rubbed intoథ the soles of the feet of a boy of 12 appeared later in his breath. ${ }^{15} \stackrel{0}{?}$ An early reference to halitosis caused by smoking stated:꿍 "Herein is . . . a great contempt, that the sweetnesse of man's breath, being a good gift of God, should be wilfully $\frac{\text { ? }}{\mathbb{Q}}$ corrupted by this stinking smoke." 16

Smelling the breath was an essential clinical investigation for doctors in bygone days, and the importance of halitosis was overrated. Nevertheless, the breath can provide an invaluable clue to a doctor when faced with a patient first seen? in coma: the fetor hepaticus of liver failure is like the smell of 
mice or a freshly opened corpse; uraemia produces a fishy ammoniacal smell; and diabetic coma an acetone odour like sweet apples or hay. (Incidentally the breath of the child with diphtheria was easily recognised by ward sisters in fever hospitals, and I once confirmed this in a small blind trial.)

Palliative measures for halitosis include breath sweeteners, peppermint, and spearmint. Mouthwashes and antibiotics upset the balance of micro-organisms and encourage resistant strains and moniliasis-so their prolonged use is inadvisable. Chlorophyll tablets have been promoted with the idea that they absorb odours, but there is no evidence of this. Mercifully halitosis is likely to disturb only those others who come into close contact with the sufferer-and those who have it are usually unaware and friends do not tell.

\section{Clifforo Hawkins}

Honorary Consultant Physician

The Postgraduate Centre,

Queen Elizabeth Hospital,

Birmingham B15 2TQ

1 Beary MD, Cobb JP. Solitary psychosis-three cases of monosymptomatic delusion of alimentary stench treated with behavioural psychotherapy. Br $\mathcal{F}$ Psychiatry 1981;138:64-6.

2 Davidson M, Mukherjee S. Progression of olfactory reference syndrome to mania: a case report. Am F Psychiatry 1982;139:1623-4.

3 Pryse-Phillips W. An olfactory reference syndrome. Acta Psychiatr Scand 1971;47:484-510.

4 Pitts G, Brogdon L Hu, Masurat T, Pianotti R, Schumann P. Mechanism of action of an antiseptic, anti-odor mouthwash. F Dent Res 1983;62:738-42.

Tonzetich J. Direct gas chromatographic analysis of sulphur compounds in mouth air Arch Oral Biol 1971;16:587-97.

McNamara TF, Alexander JF, Lee M. The rule of microorganisms in the production of oral malodor. Oral Surg Oral Med Oral Pathol 1972;34:41-8.

7 Sato H, Ohkushi T, Kaizu T, Tsunoda M, Sato T. A study of the mechanism of halitosis occurrence in periodontal patients. Bull Tokyo Med Dent Unit 1980;21:271-8.

Tonzetich J, McBridge BC. Characterization of volatile sulphur production by pathogenic and non-pathogenic strains of oral bacteroides. Arch Oral Biol 1981;26:963-9.

9 Kostelc JG, Preti G, Zelson PR, Brauner L, Baehni P. Oral odors in early experimental gingivitis J Periodont Res 1984;19:303-12.

10 Lovewell R. An unexpected cause of halitosis. Br Dent $\mathcal{F}$ 1984;157:384

11 Tydd TF, Dyer NH. Pyloric stenosis presenting with halitosis. Br Med $\mathcal{J}$ 1974; iii:321.

12 Bauman D. Halitosis from isosorbide dinitrate. $\mathcal{J} A M A$ 1975;234:482.

3 O'Reilly RA, Motley CH. Breath odor after disulfiram. FAMA 1977;238:2600.

14 Goldfrank LR, Howland MA, Kirstein RH. Arsenic. In: Goldfrank LR, Weissman RS, Flomenbaum NE, Howland MA, Lewin NA, Kulberg AG, eds. Goldfrank's toxocologic emergencies, 3rd ed. Connecticut: Appleton-Century-Crofts, 1986:609-15.

emergencies, 3rd ed. Connecticut: Appleton-Century-Crofts, 1986 .60
15 Silverstine CT. Garlic breath odor. Ohio State Med I 1936;32:1233.

16 James VI and I. A counterblast to tobacco. AD 1604. Minor works of King fames VI and I. Edinburgh: Scottish Text Society, 1982:98.

\section{When a woman asks for a caesarean section}

A woman has a clear right to refuse a caesarean section, and she is entitled to a full explanation of the circumstances before she gives or withholds consent. A more difficult question is how to respond when a labouring woman asks for a caesarean section that is not medically indicated. A recent American study explored this issue by presenting 112 obstetricians with various cases that included: a normal multigravida who had sued her last obstetrician; a multigravida at term with a baby in the breech position who was assumed to be acting altruistically for the baby; a woman in advanced labour who had had a previous caesarean section and was assumed to be trying to avoid the risk of uterine rupture. $^{1}$

Unfortunately the respondents were mainly university staff rather than private practitioners and so may not have been representative. Almost all, however, said that they would have refused operation to the normal woman despite her legal history. Most would have agreed on an operation for the woman at term with the baby in the breech position, but opinion was divided about the woman who had had a previous caesarean section. The article's authors applaud the "passive paternalism" of refusing an operation to the woman with no medical problems but champion the woman's right to operation "where alternate medically acceptable treatments exist."

The serious flaw in this argument is that vaginal delivery is a virtually inevitable consequence of being in labournot a medical treatment. Interference with this process by abdominal surgery requires a major medical indication. The authors argue that in the case of the woman with a baby in the breech position any risk to the fetus would probably be avoided by caesarean section, but this is inconsistent with the results of the Los Angeles controlled trial. ${ }^{2}$ In the case of the woman in advanced labour who had had a previous caesarean section they state that maternal risk would be reduced by operation. But the remote risk to the mother of scar rupture would be outweighed by the hazards of another caesarean section. Study of maternal mortality in England and Wales shows that in women whose pregnancies reach the stage of delivery both direct and indirect death rates are about 10 times higher when delivery is by caesarean section rather than vaginal. ${ }^{3}$ Some deaths are, of course, caused by the condition that was the indication for the operation, but at least half are caused by the speration itself. ${ }^{4}$ Lower case fatality rates in some American studies ${ }^{5}$ may be due partly to failure of ascertainment, ${ }^{4}$ partly to the absence of medical indications for some operations, and partly to a higher proportion of elective operations. Emergency caesarean sections lead to much more mortality ${ }^{3}{ }^{4}$ and morbidity ${ }^{7}$ than elective ones.

A labouring woman has the right to expect that her obstetrician will not exploit her natural fears, concerns, and discomfort to perform an operation for which there is no good medical indication when the mother and baby will do best by allowing labour to continue. Support and encouragement of women with problems in labour should be part of the stock in trade of the competent team of midwife and obstetrician.

The same ethical considerations apply for the doctor asked for an unnecessary caesarean section before labour begins. Elective caesarean section is relatively safer than emergency caesarean section for the mother but not for the fetus, with risks to respiratory function ${ }^{8}$ and intellectual development. ${ }^{9}$ To the immediate hazards of any caesarean section must be added the enhanced risk in a subsequent pregnancy of requiring another operative delivery ${ }^{10}$ or of developing placenta praevia. ${ }^{11}$ Fertility is also reduced. ${ }^{12}$

In southern Brazil half of private patients have caesarean sections, and operation rates are directly related to the woman's income and inversely related to her degree of risk. ${ }^{13}$ Women thus have caesarean sections when they can afford them rather than when they need them. This illustrates what may happen when doctors move away from medical indications.

\section{MARION H HALL}

Consultant in Obstetrics and Gynaecology,

Aberdeen Maternity Hospital,

Aberdeen AB9 2ZA

1 Johnson SR, Elkins TE, Strota $C$, Phelan JP. Obstetric decision-making: responses to patients who request caesarean delivery. Obstet Gynecol 1986;67:847-50.

2 Collea JV, Chein C, Quilligan EJ. The randomised management of term frank breech presentation: a study of 208 cases. Am $\mathcal{F}$ Obstet Gynecol 1980;137:235-42. 